\title{
COMPUTER GRAPHICS AND HOW THINGS WORK IN WORLD AROUND US
}

\section{Milan BERNÁT-Renáta BERNÁTOVÁ}

\begin{abstract}
The paper reports the aspects related to Java applets creation and their application in teaching technical and natural subjects. The authors of the paper also present the Java applets he himself created and applied in the natural and technical teaching process. At the same time he emphasises the irreplaceability of didactic and professional mastership of a teacher in the teaching process using Java applet programs.
\end{abstract}

Key words: computer, teaching technical and natural subjects

\section{POČÍTAČOVÁ GRAFIKA A AKO FUNGUJÚ VECI VO SVETE OKOLO NÁS}

Resumé: Príspevok prezentuje základné aspekty tvorby Java appletov a Flash animácií a ich aplikáciu vo výučbe prírodovedných a technických predmetov. Autori v príspevku prezentujú aj vlastnú tvorbu appletov, ktorú aplikovali vo výučbe technických a prírodovedných predmetov a ktorá umožňuje prezentovat' didaktické i odborné majstrovstvo vyučujúceho.

Kl'účové slová: počítač, výučba technických a prírodovedných predmetov

\section{Research Objectives}

The main goal of our research was to create Java applets for improving natural and technical subject teaching. Our objective was not only to create an innovative system of teaching natural and technical subject but also to verify it in the conditions of real school.

For this purpose we created over two hundred Java applets in the Java environment. The applets were created, i.e. the individual static pictures and figures from the traditional printed text books or schemes included in the instructions for use in pupils' model construction kits (mechanoes) were animated (or simulated).

Moreover, on one of the applets we demonstrated the technique of the applet creation and its didactic application. The creation principles, strategies and tactics of the other applets are analogical. In general, the key point of the application of visualization may be articulated as follows: those phenomena, processes and objects that can be visualized in a traditional, it means static way (a picture or a figure in a textbook, a plastic model or other three-dimensional models such as a model construction kit, etc.) are to be visualized traditionally. Those phenomena, processes and objects which go beyond the possibilities of the traditional and conventional ways of visualization are to be realized by means of Java applets ('enlargement of a hand of knowledge').
2 Set of Selected Applets Designed for Thematic Teaching in Natural and Technical Subjects

On the contrary, the visualisation by means of a computer model may be improved by a practical and real attribute that is contained in a textbook or a model construction kit but not in an computer model.

The created collection of computer models was called: The world of natural and technical sciences (of younger pupils) in computer models (educational models designed for teaching natural sciences, technical work and essentials of ecological education at the first level of primary schools). In order to strengthen the didactic application of the computer model the names of the individual computer models begin with the words. The individual applets of the packet start with the following words: How does it work/function? or Do you know why/Do you know how...? How does the human body work? Do you know your digestive system? Do you know how it works? Do you know how your heart works? Do you know how the respiratory and circulatory systems work? Do you know how the musculoskeletal system works? Do you know how the nervous system works? Do you know how the endocrine system works? What do you know about human reproduction? How does the reflex arch work? How does the sense of sight work? How does the sense of smell work? How does the sense of touch work? How do we affect 
the environment? How does the hydrological cycle work? How does the nitrogen cycle in the nature work? How does the nitrogen cycle in the nature work? How does the feeding network in the nature work? How to produce electricity in nuclear power? How is electricity produced from hydropower? How to produce electricity in thermal power plants? How does the wiring for lighting in the living room chandelier? How does the wiring for the lighting of a long hallway? How does the wiring for lighting stairs? What is the principled nature of wiring a house? How does iron in the household? How does instant water heater? How does an electric boiler (water heater)? How does the electric refrigerator? How does the kettle? How does a traditional stairway light switch in the projects? How does the driving electric? How does the trolley drive? How does the battery charger? How does the "audion" (audio amplifier)? How does the amplifier (sound) for guitar? How does "bug" ("spy")? How does the intercom (speakerphone between rooms)? How does the "electronic babysitter" ("singing potty")? How does Domophons (home phone? How does "amplifier for hearing aids?" How does "optical telephone"? How does "Optical Network? How does a conventional "wired" phone? What is the principled nature of the activities one-amp? What is the essence of principled action and two multi-stage amplifier? How does an electronic thermometer to measure the temperature of the human body? How does personal electronic weight? How does the electronic scale in store? How does an electronic gauge for measuring blood pressure? How does electronic barometer (measuring pressure)? How does an electronic hygrometer (air)? What is the operating principle CD player? What is the operating principle $\mathrm{CD}$ recorder? What is the principled nature of $\mathrm{AD}$ converter work? What is the essence of principled action DA converter? How does electronic advertising lights? How does light "flashing" the Christmas tree? How does the flashing rear lights on your bike? How does the electronic lock on the code? How does the automatic ticketing on public transport? How does the vending machine? How does the electronic control operation of traffic lights at the crossroads? How do electronic digital timer? How does the alarm clock? How does the electronic timing for the athletic oval? How does automatic mail sorter at the post office? How does an electronic speedometer on the bike? How does the electronic counting money in the bank? How does the timer for switching on and off electrical appliances? How does automatic dishwasher? How does the washing machine? How does automatic washing machine ? What is the essence of principled action "steps chain"? How does electronic siren? How do electronic organ? How does the bell with the melody? How does an electronic metronome? How does the connection from the mobile network? How does the electronic digital control panel? How does an electronic calculator? How does using an electronic cash register barcode scanner in the store? How does e-assessment in the play "arrow"? How does the arithmetic logic unit of the computer? How does the counting adder for two binary numbers? How does a microprocessor?

Fig 1: The applet - Do you know the activity of the human heart?
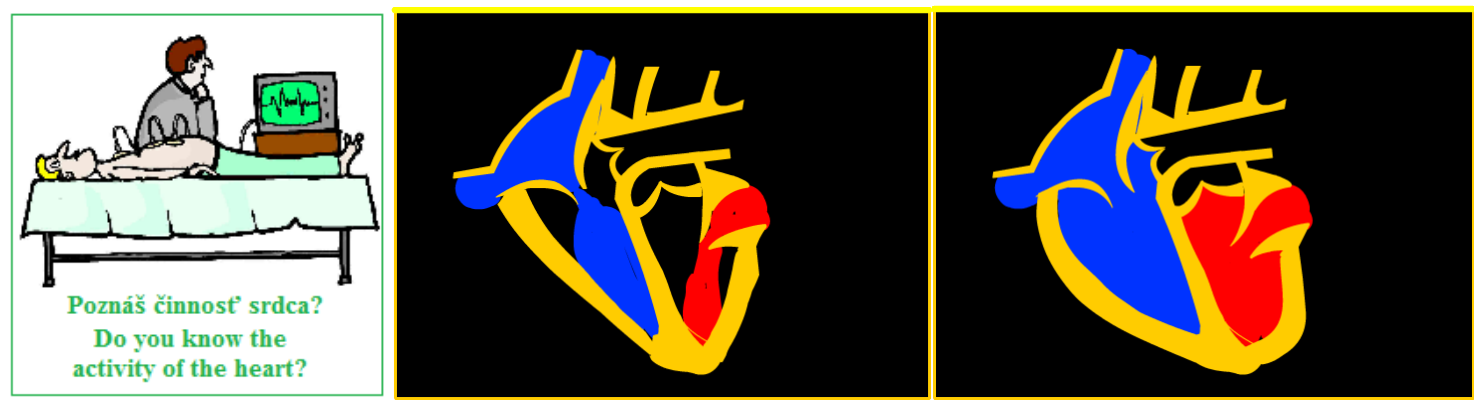
Fig 2: The applet - Understand why the aternate phases of The Moon?
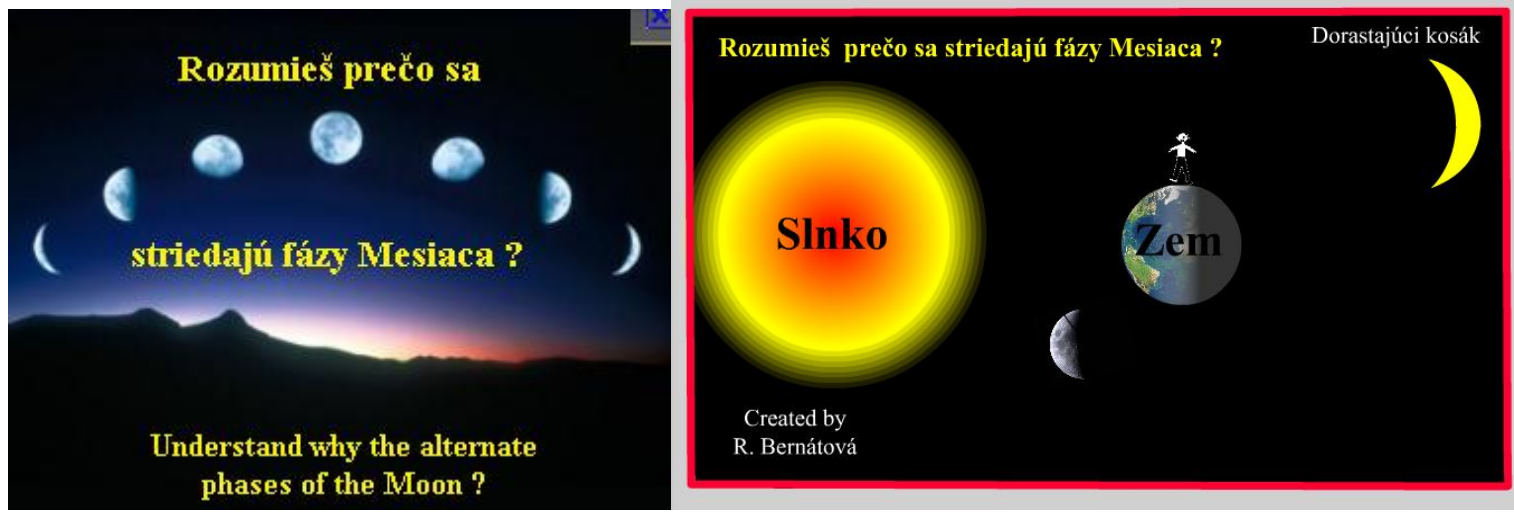

Fig 3: The applet - Do you know the activity of the digestive tract in humans?
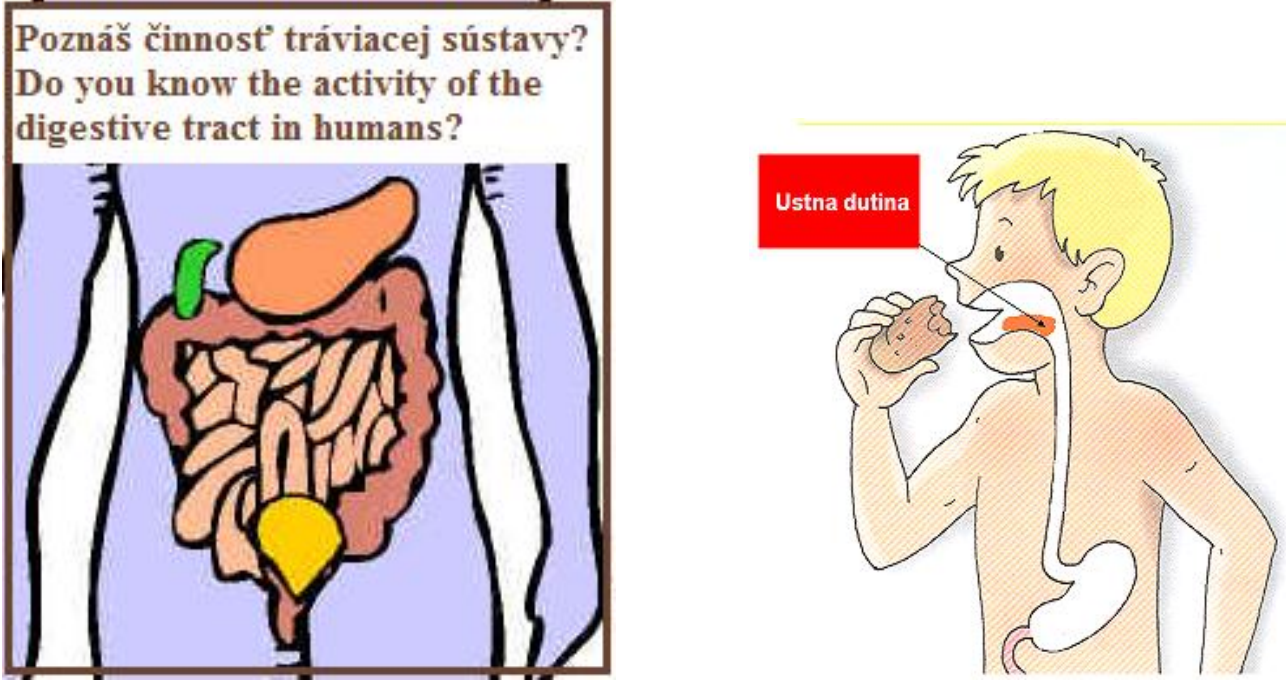

Fig 4: The applets - "Want to know why the alternate seasons?"
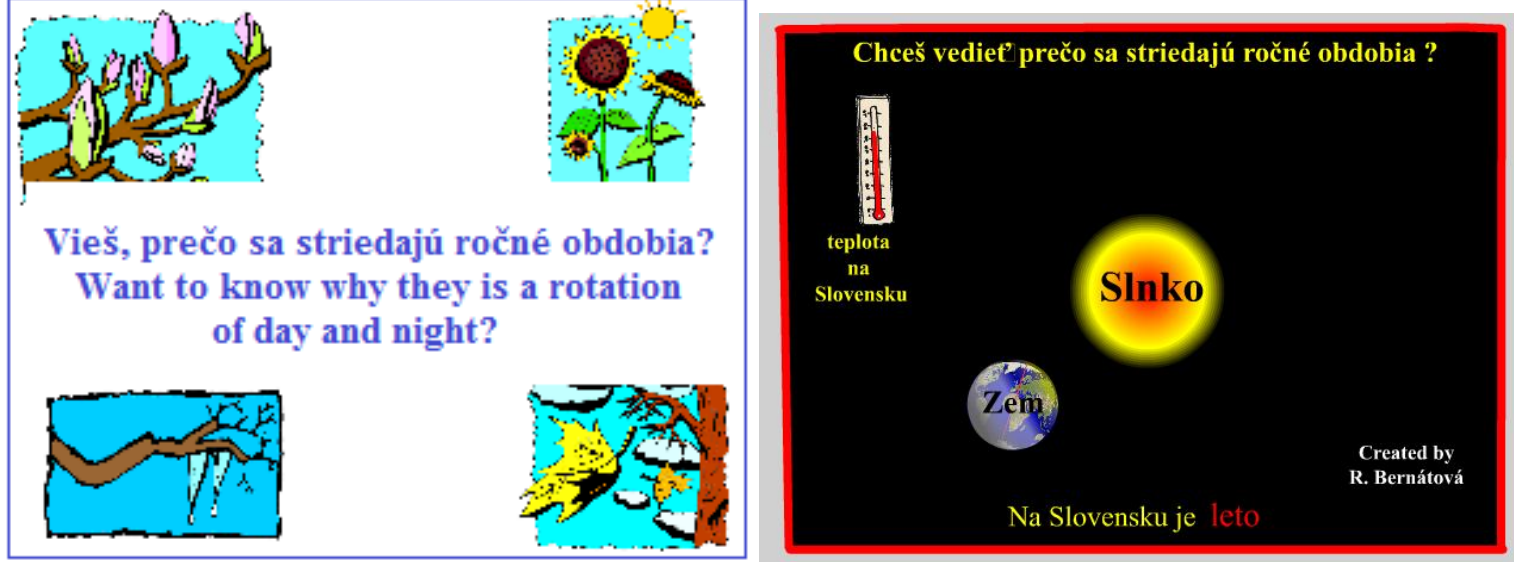
Fig 5: The applet - How does the electronic digital stopwatch work?

\section{Chceš vediet'?}

Ako fungujú elektronické digitálne stopky? How does the electronic digital stopwatch work?

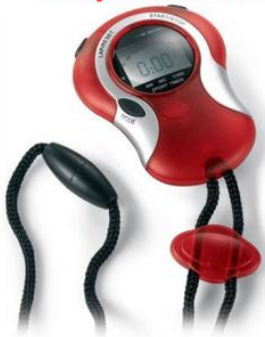

Created Milan Bernát

\section{AKO FUNGUJÚ DIGITÁLNE HODINY?}
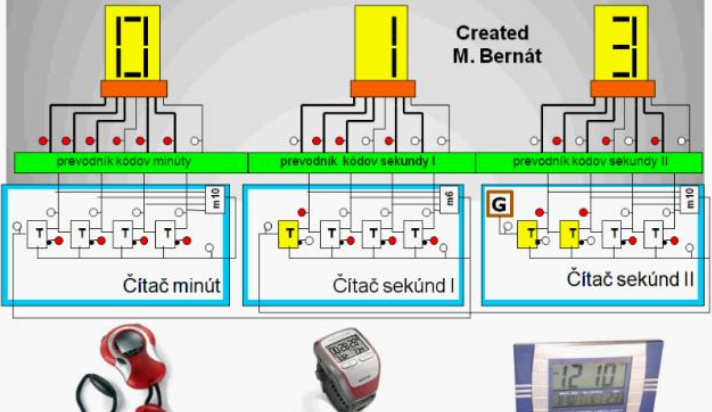

Fig 6: The applet - How does the electronical bath scales work?

\section{Chceš vediet' ?}

Ako funguje osobná elektronická váha? How does the electonical bath scales work?

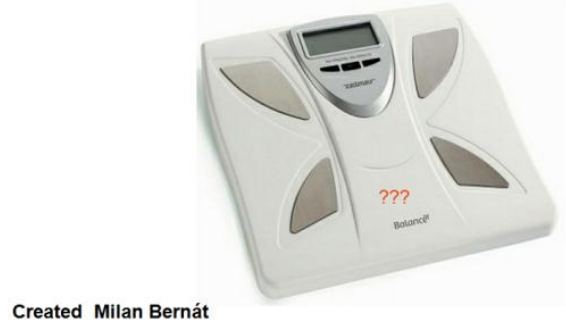

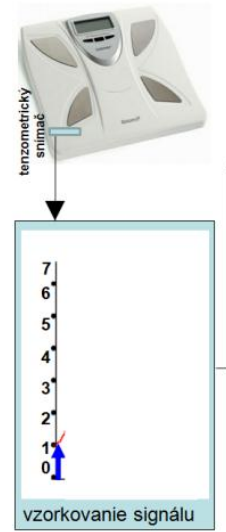

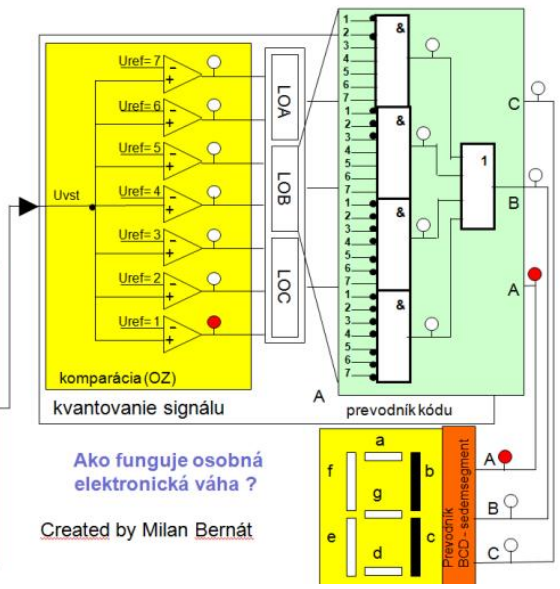

Fig 7: The applet - How does the principal nature drive trams?
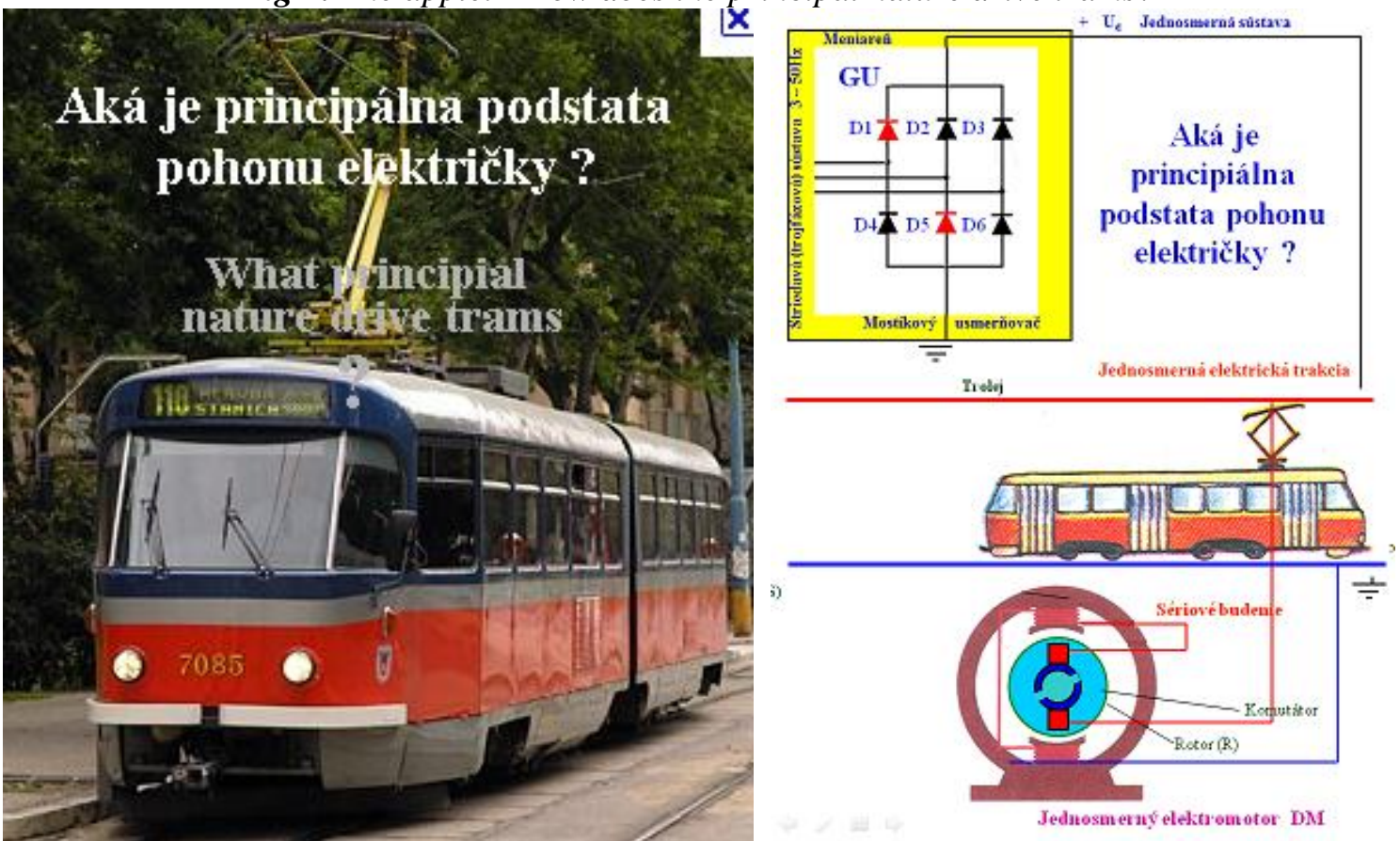
Fig 8: The applet-How does the automatic garage door openers
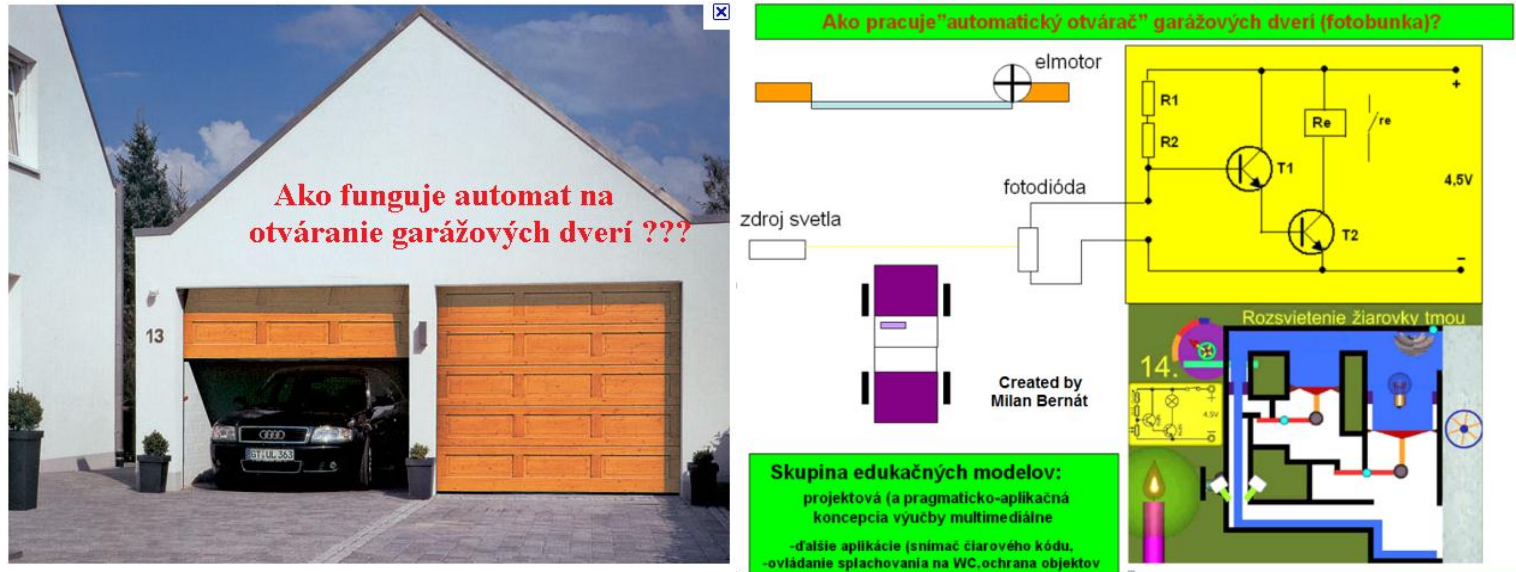

Fig 9: The applet - How does control the transport of bulk materials?

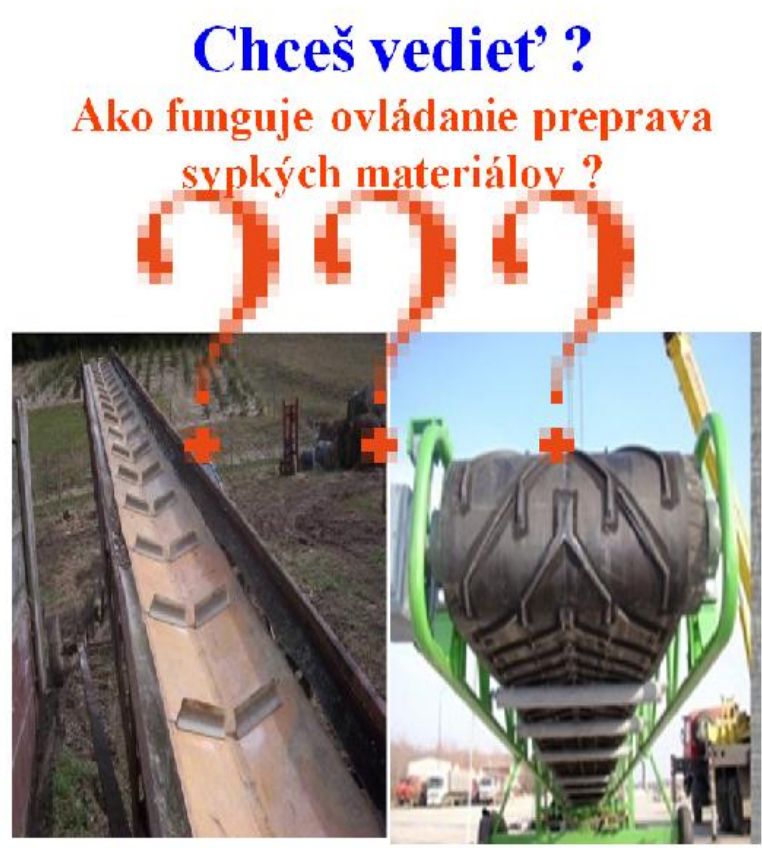

Created Milan Bernát

\section{Research sample}

The research sample consisted of 118 pupils of the 4th grade from the five primary schools of the eastern region. Pupils of the 4th grade forming a research sample were on the basis of results achieved in the input didactic tests divided into experimental and control group. 58 pupils were placed in the experimental group and 60 pupils in the control group. Pedagogical experiment was carried out from January to June 2011. In the experimental group, there was applied the

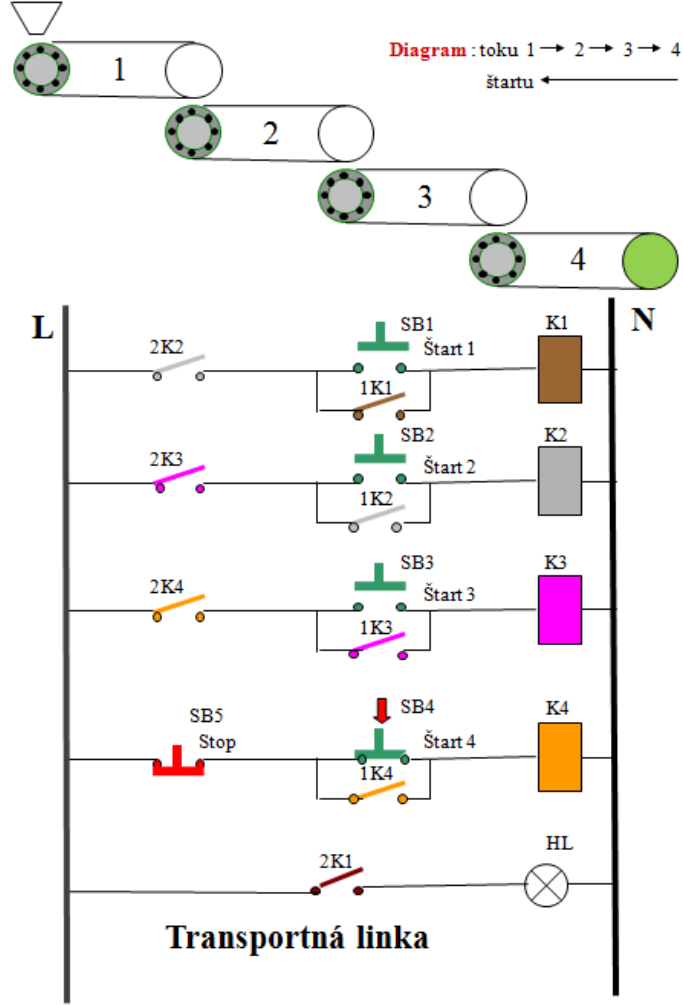

computer supported curriculum of the natural sciences (using the computer visualization of the system of the logical structure of curriculum) and in the control group, there was education carried out without computer support (using traditional way of teaching).The comparison of results showed that pupils of experimental group achieved in the continuous didactic test from the natural science for the 4th grade of $70,05 \%$ success in solving, pupils of control group of $60,22 \%$ (see Graph 1). 
Graph 1 Percentage of successful solution of the continuous didactic test by experimental and control group

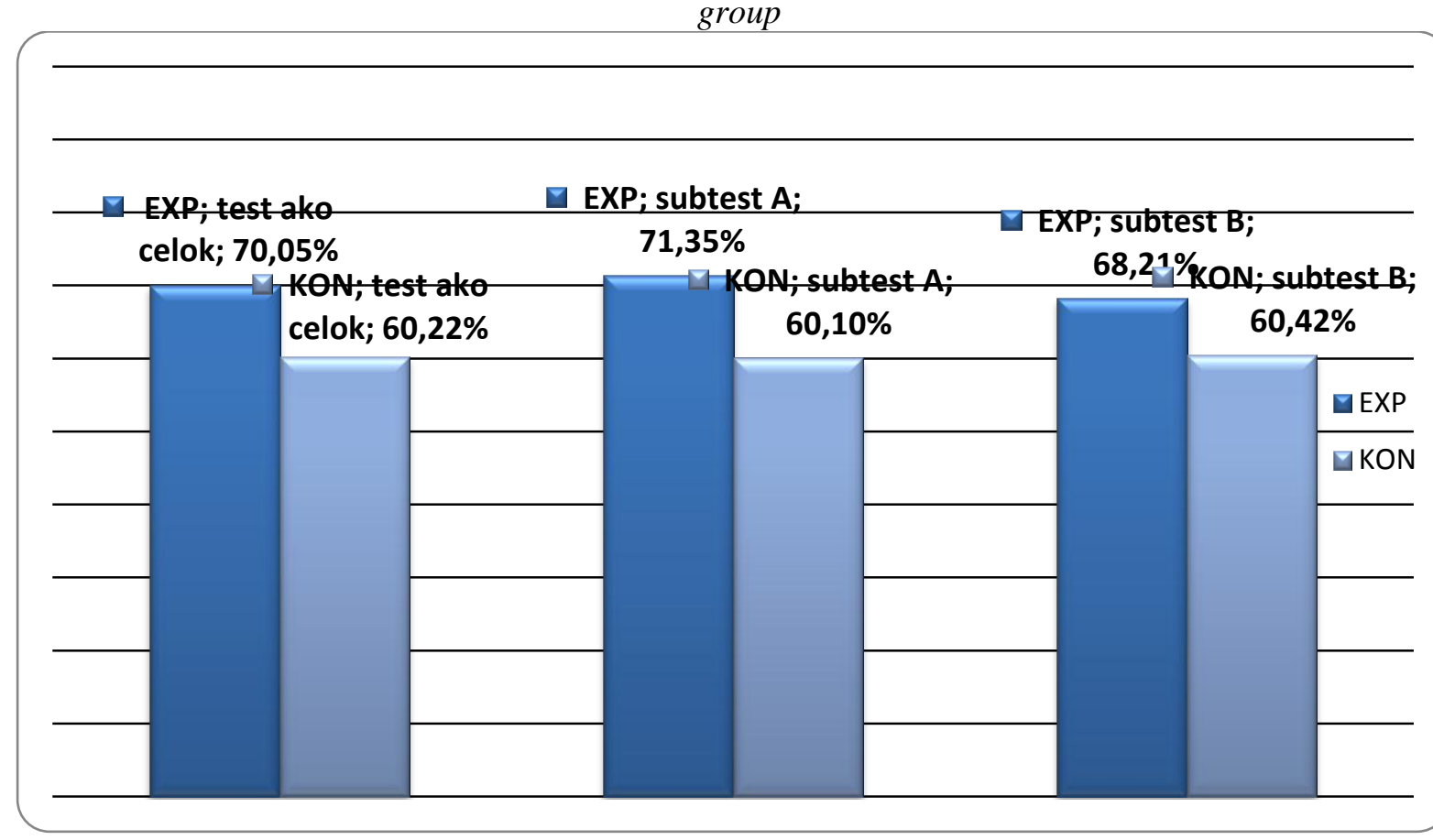

Statistical significance of the difference between experimental and control group in performance of individual subtests of the continuous didactic test is illustrated by the following tables.

\section{Conclusion}

In conclusion, we would like to say that we present only partial results of the continuous pedagogical experiment in the article, which we implement in the second, third and fourth grade of primary school in the curriculum of natural science subjects. The current results described in our article show that computer-supported learning of natural science subjects (applying computer visualization of the system of the logical structure of curriculum) in the 4th grade of primary school has a positive impact on the acquisition of the educational contents of the natural sciences by primary school pupils.

The article was created as part of a project KEGA 200-030PU-4/2010 and project VEGA 1/0642/09.

\section{References}

[1] BERNÁTOVÁ, R., BERNÁT, M. Technika vizualizácie systému logickej štruktúry biologického a biofyzikálneho učiva na báze jeho kybernetickej podstaty I. In: Technológia vzdelávania, č. 3, roč. XII., s. 12-14. Nitra: Slovdidac, 2004. ISSN 1335-003X

[2] BERNÁT, M. Visualization of some electrophysical processes through computer for didactic purposes and its application in teaching electrotechnical subjects. PhD. thesis, PdF UKF Nitra 2005 (in Slovak).

[3] MELEZINEK, A. Ingenieurpädagogik: Praxis der Vermittlung technische Wissens techn. Wissens. Wien, New York, Springer, 1986.

[4] WIKIPEDIA:http://en.wikipedia.org/wiki/

\section{Doc. Ing. Milan Bernát, PhD}

Doc. RNDr. Renáta Bernátová, PhD.

Prešovská univerzita v Prešove

Fakulta humanitných a prírodných vied

Pedagogická fakulta

Ul. 17. novembra 15, 08001 Prešov, SR

Tel.: +421517570771, +421517470586

E-mail:bernatt@centrum.sk, renata.bernatova@pf.unipo.sk Www pracoviska: www.unipo.sk 